\title{
Changes in Serotonin Modulation of Glutamate Currents in Pyramidal Offspring Cells of Rats Treated With 5-MT during Gestation
}

\author{
Gustavo Hernández-Carballo ${ }^{1} \oplus$, Evelyn A. Ruíz-Luna ${ }^{1}$, Gustavo López-López ${ }^{2}$, \\ Elias Manjarrez ${ }^{1}$ and Jorge Flores-Hernández ${ }^{1, *(D)}$ \\ 1 Instituto de Fisiología Benemérita Universidad Autónoma de Puebla, Puebla C.P.72570, Mexico; \\ l.gustavoh.carballo@gmail.com (G.H.-C.); evy_0927@hotmail.com (E.A.R.-L.); \\ eliasmanjarrez@gmail.com (E.M.) \\ 2 Facultad de Ciencias Químicas Benemérita Universidad Autónoma de Puebla, Puebla C.P.72570, Mexico; \\ jose.lopez@correo.buap.mx \\ * Correspondence: jorge.flores@correo.buap.mx; Tel.: +52-222-229-5500 (ext. 7325)
}

Received: 27 February 2020; Accepted: 3 April 2020; Published: 8 April 2020

\begin{abstract}
Changes in stimuli and feeding in pregnant mothers alter the behavior of offspring. Since behavior is mediated by brain activity, it is expected that postnatal changes occur at the level of currents, receptors or soma and dendrites structure and modulation. In this work, we explore at the mechanism level the effects on Sprague-Dawley rat offspring following the administration of serotonin (5-HT) agonist 5-methoxytryptamine (5-MT). We analyzed whether 5-HT affects the glutamate-activated $\left(\mathrm{I}_{\mathrm{Glut}}\right)$ and N-methyl-D-aspartate (NMDA)-activated currents ( $\left.\mathrm{I}_{\mathrm{Glut}}, \mathrm{I}_{\mathrm{NMDA}}\right)$ in dissociated pyramidal neurons from the prefrontal cortex (PFC). For this purpose, we performed voltage-clamp experiments on pyramidal neurons from layers V-VI of the PFC of 40-day-old offspring born from 5-MT-treated mothers at the gestational days (GD) 11 to 21 . We found that the pyramidal-neurons from the PFC of offspring of mothers treated with 5-MT exhibit a significant increased reduction in both the $\mathrm{I}_{\mathrm{Glut}}$ and $\mathrm{I}_{\mathrm{NMDA}}$ when 5-HT was administered. Our results suggest that the concentration increase of a neuromodulator during the gestation induces changes in its modulatory action over the offspring ionic currents during the adulthood thus contributing to possible psychiatric disorders.
\end{abstract}

Keywords: neurotransmitters; development; neurodevelopment; neuromodulation; 5-HT; hyperserotonemia; 5-MT; glutamate; NMDA; ionic currents

\section{Introduction}

The study of neuromodulators and their influences on voltage-gated and synapse-driven currents are of great interest [1-7]. In particular, 5-HT catches our attention for its wide distribution on the brain, as well as its role in a large number of behaviors that range from learning and memory to social behavior [8-10]. Also, increasing evidence points to alteration of 5-HT signaling as a crucial development component of multiple psychiatric conditions such as schizophrenia, mood disorders, anxiety, and depression [11-14].

Neuromodulators play an orchestrator role in cellular proliferation, migration, and differentiation during gestational development, giving shape to neuronal communication and circuits [15-18]. In this context, the study of the 5-HT system is highlighted due to its early development, which is evident from the fifth week of gestation in humans [19] and GD12 in rodents [20,21]. However, the expression of receptors and other serotoninergic structures before the development of its innervation [22] suggests the existence of an exogenous source of 5-HT, which is maternal-placental [23]. 
Several works have proposed that altering serotonergic homeostasis during offspring's pre- and post-natal development results in a predisposition to psychiatric disorders [24-28]. Studies where the concentration of 5-HT is alterd in sensitive or critical periods of fetal development show behavioral, cognitive, and emotional abnormalities [29,30], as well as changes in dendritic complexity [31,32] and cellular survival [33] and migration [34,35]. In particular, the artificial increase in the concentration of serotonin using 5-HT transporters (SERT) or monoamine oxidase (MAO) inhibitors, and 5-HT agonists such as 5-MT, induces several brain disorders, for instance, affective-abnormalities, cognitive and fear extinction deficiencies, anxiety-like behaviors [36,37], changes in the expression of 5-HT receptors [38-40], abnormalities in the laminar and columnar organization [41-43] and the excitability of areas such as the PFC [44].

Particularly, the PFC is densely innervated by axons from the main monoaminergic nuclei, such as the ventral tegmental area and raphe nuclei, which in turn receive projections from the deep layers of the PFC as do multiple cortical and subcortical regions [45]. For this reason, alteration or failure of the processes that regulate the development of proper PFC functioning results in reduced intercommunication within areas [46-48], as well as changes in the chemical balance that contributes to multiple cognitive deficits observed in various neuropsychiatric disorders [49].

Through the use of optogenetic inhibition of layer $\mathrm{V}$ pyramidal neurons on the valproic acid model [50] or the construction of genetic co-expression networks [51], studies show that neurons in the prefrontal cortex found in layers V-VI are related to the etiology of autism, identifing the fetal stage as the time of greatest sensitivity to the mutations responsible of the disorder.

Based on the foregoing, this work aims to demonstrate the effect of 5-HT on $\mathrm{I}_{\mathrm{NMDA}}$ and $\mathrm{I}_{\mathrm{Glut}}$ in dissociated pyramidal neurons of the offspring of rats treated with a serotonergic agonist during pregnancy. We demonstrate that treatment has a controlling influence on the modulatory action of 5 -HT on $\mathrm{I}_{\mathrm{NMDA}}$ and $\mathrm{I}_{\mathrm{Glut}}$.

We consider that our work contributes to the understanding and interpretation of the effect of maternal stress and inflammation during pregnancy since both increase the placental output of 5-HT to the fetal brain [27,52-55]. An increasing amount of evidence associates the use of selective 5-HT reuptake inhibitors (SSRIs) during pregnancy with changes in brain morphology and neurodevelopmental disorders [56-58]. In the present study, 5-MT, a non-selective serotonin agonist, was applied to pregnant rats in order to examine whether or not such treatment alters the offspring's serotonergic modulation of $\mathrm{I}_{\mathrm{NMDA}}$ and $\mathrm{I}_{\text {Glut }}$.

Our results indicate that the offspring from mothers treated with 5-MT during gestation exhibit a statistically significant increase in the 5-HT inhibitory effect on the $\mathrm{I}_{\mathrm{NMDA}}$ and $\mathrm{I}_{\text {Glut }}$ amplitude. Our work is relevant because it shows for the first time that the synapse-driven currents in the brains of offspring, whose mothers were treated with neuromodulators during the gestation, are affected by the same neuromodulators in a different way as the offspring whose mothers were not treated with such neuromodulators. Moreover, our results could lead to the development of new fields in the study of other currents and experimental models.

Furthermore, studies like this are necessary because they offer evidence that alterations in 5-HT levels during gestation lead to severe pathologies in the neural circuits of the offspring. Such is the case of an autism hypothesis [59]. However, works pointing to this hypothesis have only analyzed it at a behavioral level, not at the level of electrophysiological mechanisms.

\section{Materials and Methods}

All protocols and procedures employed in this study were reviewed and approved by the institutional board of bioethics (VIEP/1944/2016) and followed the national (NOM-062-ZOO-1999) and international guidelines of care and use on experimental animals. 


\subsection{Animals}

We used pregnant Sprague-Dawley dams with GD0 to GD8 obtained from the vivarium "Claude Bernard" from the Benemérita Universidad Autónoma de Puebla. Dams were housed individually at a temperature/humidity controlled environment in a $12 \mathrm{~h}$ light and dark cycle, with ad libitum access to water and food and were assigned to a group using a double-blind design.

For the first part of this study, we used three groups. The first group (5-MT Pre-Post) follows procedures described for Whitaker-Azmitia [59] in order to reproduce the developmental hyperserotonemia (DHS) model of autism. From GD11 to delivery, pregnant dams received a single daily subcutaneous injection of $1 \mathrm{mg} / \mathrm{kg}$ 5-MT (non-selective 5-HT agonist) dissolved in the vehicle ( $0.85 \%$ saline with no more than $0.4 \%$ dimethylsulfoxide). After birth, pups were treated with 5-MT at the same dose (1 mg/kg) until weaning (postnatal day 24; PND24), thereupon only the male offspring were kept for further electrophysiological analysis in order to reduce the effects of hormonal-cyclic periods in females. The second group (5-MT Gest) follows the same methodology without the administration of pups after delivery. Finally, mothers from the third group (Control) were injected only with the vehicle as well as the pups.

After the first experiment, only the 5-MT Gest and Control groups were maintained. For this part of the study, only the dams were treated in both the 5-MT Gest and the Control groups.

For each electrophysiological protocol, at least three offspring from no less than two different litters were used.

\subsection{Reagent}

Unless otherwise stated, all reagents purchased were from Sigma-Aldrich (St. Louis, MO, USA).

\subsection{Acute-Dissociation Procedure}

PFC neurons from young adults (PND40-PND60) were acutely-dissociated using procedures similar to those described previously [60-62]. Dissection of the PFC was limited to V-VI layers, where is the highest density of serotoninergic receptors [63].

Slices were maintained between one and six hours at room temperature $\left(20-22{ }^{\circ} \mathrm{C}\right)$ in Earle's balanced salt solution (EBSS), buffered with sodium bicarbonate $\left(\mathrm{NaHCO}_{3}\right)$, supplemented with $1 \mathrm{mM}$ pyruvic acid, $0.005 \mathrm{mM}$ glutathione, $0.1 \mathrm{mM}$ NG-nitro-L-arginine and $1 \mathrm{mM}$ kynurenic acid, and bubbled with $95 \% \mathrm{O}_{2} / 5 \% \mathrm{CO}_{2}$. The $\mathrm{pH}$ was adjusted to 7.4 with sodium hydroxide $(\mathrm{NaOH})$, and osmolarity adjusted to $300 \mathrm{mOsm} / \mathrm{L}$.

After at least one hour of incubation, the PFC slices were prepared for enzymatic treatment. Each slice then was placed in a culture chamber containing $40 \mathrm{~mL}$ of Hank's balanced salt solution (HBSS) mixed with $0.75 \mathrm{mg} / \mathrm{mL}$ of papain, buffered with 4-(2-hydroxyethyl)-1-piperazineethanesulfonic acid (HEPES), bubbled with $\mathrm{O}_{2}$ and maintained at $35^{\circ} \mathrm{C}$ for ten minutes. The solution was supplemented in the same way as the EBSS.

After enzymatic digestion, the tissue was washed with a solution of isethionate and later mechanically separated with various sizes of fire-polished Pasteur pipettes. Suspensions of cells were seeded in 35-mm polystyrene Petri dishes (Corning Inc., Corning, NY, USA) mounted on the recording chamber coupled to an inverted microscope. After ten minutes of incubation, the suspension was washed

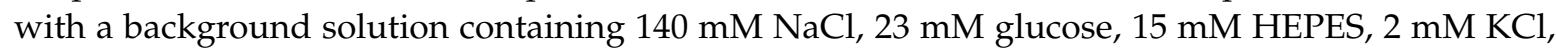
$2 \mathrm{mM} \mathrm{MgCl}, 1 \mathrm{mM} \mathrm{CaCl}_{2}$ and $1 \%$ phenol red, bubbled with $\mathrm{O}_{2} \mathrm{pH}$ was adjusted to 7.4 with $\mathrm{NaOH}$ and osmolarity adjusted to $300 \mathrm{mOsm} / \mathrm{L}$ to prepare the tissue for subsequent recording using the voltage-clamp technique.

\subsection{Whole-Cell Patch-Clamp Technique}

Whole-cell voltage-clamp was used to record $\mathrm{I}_{\mathrm{Glut}} / \mathrm{I}_{\mathrm{NMDA}}$ in dissociated pyramidal-neurons from the PFC. Recording electrodes were pulled from borosilicate capillary tubes (1B120F-4, WPI, Sarasota, 
Florida, USA) with a micropipette puller (P-97, Sutter Instruments, CO, USA) and a resistance ranging from 4 to $8 \mathrm{M} \Omega$.

The internal solution consisted of $175 \mathrm{mM}$ N-methyl-D-glutamine (NMDG), $40 \mathrm{mM}$ HEPES, $2 \mathrm{mM} \mathrm{MgCl} 2,10 \mathrm{mM}$ ethylene glycol-bis ( $\beta$-aminoethyl ether)- $\mathrm{N}, \mathrm{N}, \mathrm{N}^{\prime}, \mathrm{N}^{\prime}$ - tetra acetic acid (EGTA), $12 \mathrm{mM}$ phosphocreatine, $3 \mathrm{mM} \mathrm{Na} 2 \mathrm{ATP}, 0.35 \mathrm{mM} \mathrm{Na}_{3} \mathrm{GTP}$ and $0.1 \mathrm{mM}$ leupeptin, adjusted to a $\mathrm{pH}$ of 7.3 with $\mathrm{H}_{2} \mathrm{SO}_{4} / \mathrm{NMDG}$ and 265-270 mOsm/L. The external solution consisted of $127 \mathrm{mM} \mathrm{NaCl}$, $20 \mathrm{mM} \mathrm{CsCl}, 5 \mathrm{mM} \mathrm{BaCl}_{2}, 2 \mathrm{mM} \mathrm{CaCl}_{2}, 12 \mathrm{mM}$ glucose, and $10 \mathrm{mM}$ HEPES, adjusted to a $\mathrm{pH}$ of 7.4 with 300-305 mOsm/L NaOH. Additionally, $10 \mu \mathrm{M}$ glycine was added to the external solution as an NMDA co-agonist for channel activation by glutamate or NMDA [64]. Recordings were obtained with an Axopatch 1-D voltage-clamp amplifier (Molecular Devices, Sunnyvale, CA, USA), controlled with a pCLAMP version 9 (Molecular Devices, Sunnyvale, CA, USA) and a Digidata 1322A digitizer (Molecular Devices, Sunnyvale, CA, USA).

Once the seal was broken, only cells with an input resistance $\left(R_{I N}\right)$ of less than $25 \mathrm{M} \Omega$ were included in the study. The holding potential was set at $-80 \mathrm{mV}$ to record $\mathrm{I}_{\mathrm{Glut}} / \mathrm{I}_{\mathrm{NMDA}}$. Potassium was blocked by the $\mathrm{Cs}^{+}$and $\mathrm{Ba}^{++}$present in the external solution.

\subsection{Drug Application}

We induced the $\mathrm{I}_{\text {Glut }}$ and $\mathrm{I}_{\mathrm{NMDA}}$ currents by applying the compounds using a system of two capillaries placed at $45^{\circ}$ to each other and a distance of $300 \pm 100 \mu \mathrm{m}$ from the recorded cell. One capillary contained the external solution with or without the tested neuromodulator (External $\pm \mathrm{NM}$ ), and the other had External \pm NM and glutamate or NMDA as required (Figure 1). The solution was changed using solenoid valves (98302-00, Cole-Parmer) controlled by the digital output of the Digidata 1322A system and a control apparatus designed in our laboratory.

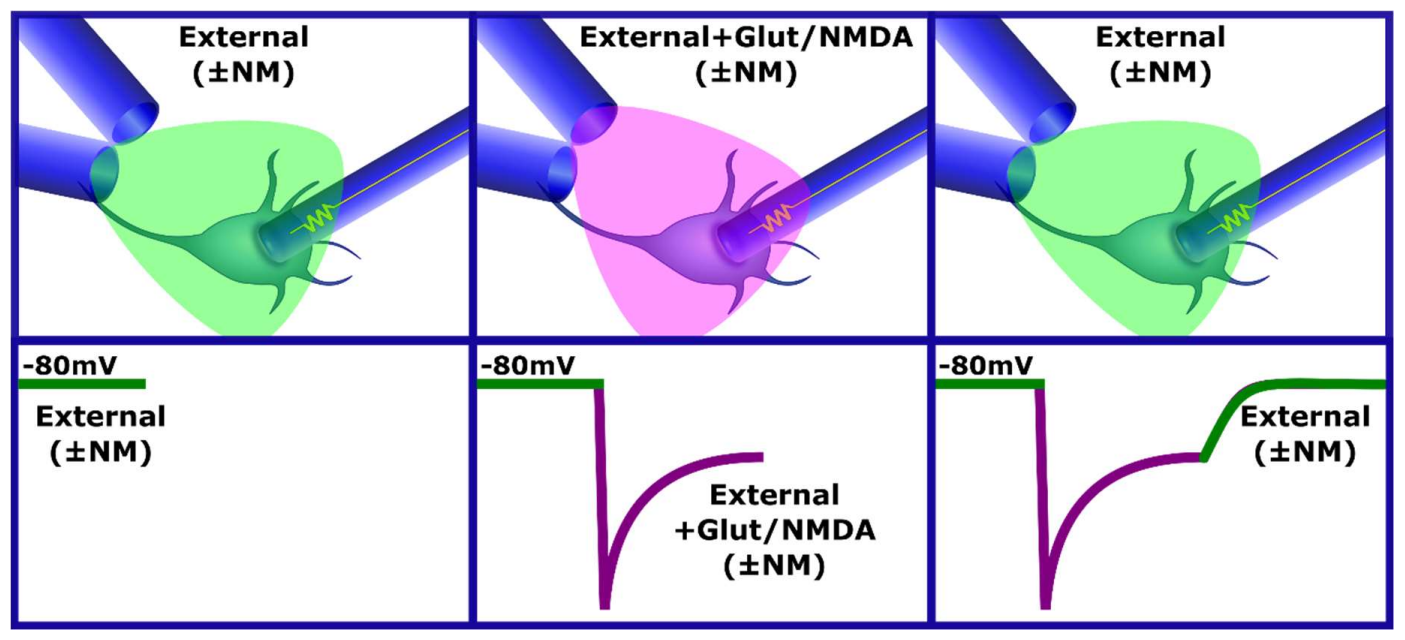

Figure 1. Application of solutions using capillaries. The application of solutions was controlled using solenoid valves; one capillary contained the external solution with or without the tested neuromodulator $($ External $\pm \mathrm{NM})$, and the other had External $\pm \mathrm{NM}$ and Glutamate or N-methyl-D-aspartate (NMDA) as required. In the bottom panels, there are representative traces of the NMDA-current where the effect of the application of each solution is illustrated.

During each protocol, we maintained the potential at $-80 \mathrm{mV}$, and we recorded the activity at a sampling frequency of $403.23 \mathrm{~Hz}$ (every $2.48 \mathrm{~ms}$ ). Each sweep lasted six seconds during which the cell was constantly perfused with the external solution with a three-second interruption during which external solution + glutamate (or NMDA) was applied. This condition was maintained until three or four stable current traces were obtained. This same procedure was then repeated by adding the neuromodulator of interest to the external solution. The condition without the neuromodulator was considered as a reference and washing of the effect of the neuromodulators on the current. 
We randomly exposed each cell to different neuromodulators or concentrations used in the assigned electrophysiological protocol in order to balance the time-course and cell-viability-induced changes.

\subsection{Statistical Analysis}

We obtainded the neuromodulators effect $\left(5-\mathrm{HT}\right.$ or $\left.\mathrm{Mg}^{++}\right)$as the reduction in the amplitude of the peak or steady-state (SS) of the $\mathrm{I}_{\mathrm{Glut}}$ or $\mathrm{I}_{\mathrm{NMDA}}$ according to the control and wash conditions. We calculated the percent reduction as follows:

$$
\% \text { Reduction }=\left(1-\frac{\delta I L}{((\delta I R+\delta I W) / 2)}\right) \times 100
$$

where $\delta I R$ is the $I_{G l u t}$ or $I_{N M D A}$ density without the neuromodulator (reference condition), $\delta I W$ is the $\mathrm{I}_{\mathrm{Glut}}$ or $\mathrm{I}_{\mathrm{NMDA}}$ density in the wash condition, and $\delta \mathrm{IL}$ is the $\mathrm{I}_{\mathrm{Glut}}$ or $\mathrm{I}_{\mathrm{NMDA}}$ density in the presence of the neuromodulator tested. We report values as the mean \pm standard error of the mean (SEM). We generated curve fits in Origin 9.1 (Microcal Software Inc., North Hampton, MA, USA) and compared with F-test in the form:

$$
F=\frac{\left(\left(S_{M}-\left(S_{C}+S_{T}\right)\right) / k\right)}{\left(\left(S_{C}+S_{T}\right) /\left(N_{C}+N_{T}-2 k\right)\right)},
$$

where $S_{M}$ is the residual sum of squares (RSS) for the fit of the combined data of both models, $S_{C}$ is the RSS for the fit of the control group, $S_{T}$ is the RSS for the fit of the tested group, $N_{C}$ and $N_{T}$ is the number of observations for the control and the tested group, respectively, and $k$ is the number of parameters of the fit. This statistic test follows the $\mathrm{F}$ distribution with $k$ and $\mathrm{N}_{1}+\mathrm{N}_{2}-2 k$ degrees of freedom. The statistical comparisons were performed with the help of the extension package $d r c$ [65] for the statistical environment $R$ [66].

We performed the data analysis using a Student's $t$-test with Welch's correction or analysis of variance (ANOVA) followed by a multiple comparison test, as appropriate, with the significance set at $p<0.05$.

\section{Results}

We treated a total of 34 pregnant rats for all the experiments presented in this manuscript, 16 with vehicle only and 18 with 5-MT. From these dams, we used 56 pups to obtain a total of 123 cells: 68 belong to the 16 offspring of the control group, 55 cells from the 14 offspring of mothers treated with 5-MT Gest treatment, and 13 cells belong to 4 with 5-MT Pre-Post treatment. The sample only included recorded neurons with a membrane resistance $\geq 1 \mathrm{G} \Omega$ and an input resistance $<25 \mathrm{M} \Omega$. The average of the input resistance for the 123 cells was $17.66 \mathrm{M} \Omega$, with a standard deviation (SD) of $5.42 \mathrm{M} \Omega$.

We determined the cells' size by measuring the cell capacitance and using a capacitance/area ratio of $1 \mu \mathrm{F} / \mathrm{cm}^{2}$. The average cell capacitance for the control group was 19.46 and $19.03 \mathrm{pF}$ for the 5-MT Gest, with an SD of 4.92 and $5.63 \mathrm{pF}$, respectively, with no significant difference between groups $\left(\mathrm{t}_{108.11}\right.$ $=0.45, p=0.65)$. We only compared cells of the 5-MT Pre-Post group $(n=13$, average $=14.55 \mathrm{pF}, \mathrm{SD}$ $=4.18 \mathrm{pF}$ ) with those of the control and 5-MT Gest groups used in the same experiment (10 and 12, respectively) because of the small number of cells of this group. No significant difference between the groups was found in this comparison (one way ANOVA $F_{2,32}=1.14, p=0.33$ ).

In each experiment, we evaluated cellular viability with a voltage-clamp ramp (from -100 to $+40 \mathrm{mV})$ lasting $300 \mathrm{~ms}$ to generate $\mathrm{Na}^{+}\left(\mathrm{I}_{\mathrm{Na}}+>1 \mathrm{nA}\right)$ and $\mathrm{Ca}^{++}\left(\mathrm{I}_{\mathrm{Ca}}++>100 \mathrm{pA}\right)$ currents. We excluded any cell with values lower than these from the analysis.

\subsection{5-MT Treatment from GD11 to GD21 Increases the 5-HT Effect on $I_{\text {Glut }}$}

To test the hypothesis that the alteration of 5-HT concentrations of mothers during pregnancy is capable of changing the way 5 -HT modulates $\mathrm{I}_{\mathrm{Glut}}$ of offspring in a life-lasting way, we examined the serotonergic modulation of $\mathrm{I}_{\mathrm{Glut}}$ in acutely dissociated PFC pyramidal neurons of 40 days old offspring 
from Sprague-Dawley rats treated with the 5-HT agonist 5-MT from GD11 to GD21 and from GD11 to PND21.

To initiate, we compared a gestational-only treatment (GD11-GD21; "5-MT Gest"; $n=10$ ) with the original DHS model (GD11-PND21; “5-MT Pre-Post"; $n=13)$ and a control group $(n=12)$. In particular, we examined whether the 5-MT treatment affects the 5-HT modulation of the $\mathrm{I}_{\mathrm{Glut}}$ and, whether the gestational treatment alone is capable of producing a statistically significant difference from the control. Moreover, we conducted a one-way between-groups ANOVA to compare the effects of treatments on $\mathrm{I}_{\mathrm{Glut}}(100 \mu \mathrm{M})$ in the presence of 5-HT $(30 \mu \mathrm{M})$. The peak amplitude and SS of $\mathrm{I}_{\mathrm{Glut}}$ were analyzed (Figure 2), finding significant differences of 5-HT effect on both peak amplitude $\left(\mathrm{F}_{2,32}=16.18 ; p<0.001\right)$ and SS $\left(\mathrm{F}_{2,32}=17.88 ; p<0.001\right)$. Post-hoc comparisons using the Tukey test $(p<0.05)$ indicated that both 5-MT Gest and 5-MT Pre-Post groups are significantly different from the control but no significantly different from each other (Table 1). Altogether, these results suggest that the treatment with 5-MT during an early developmental stage, particularly the period between GD11 and GD21, produces a significant change in the $\mathrm{I}_{\mathrm{Glut}}$ during the presence of 5-HT.

A)

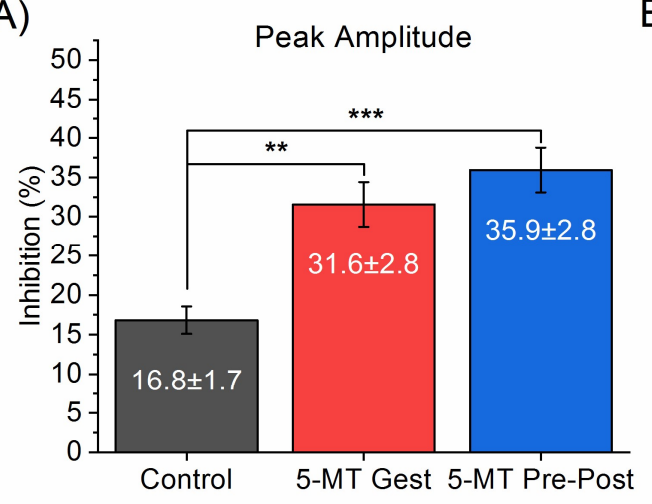

B)

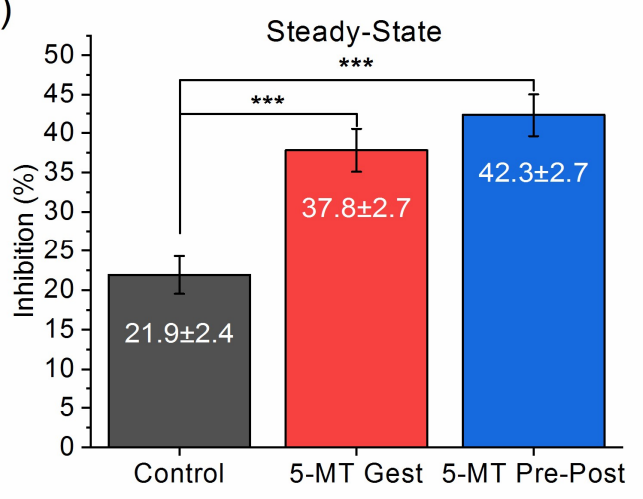

C)

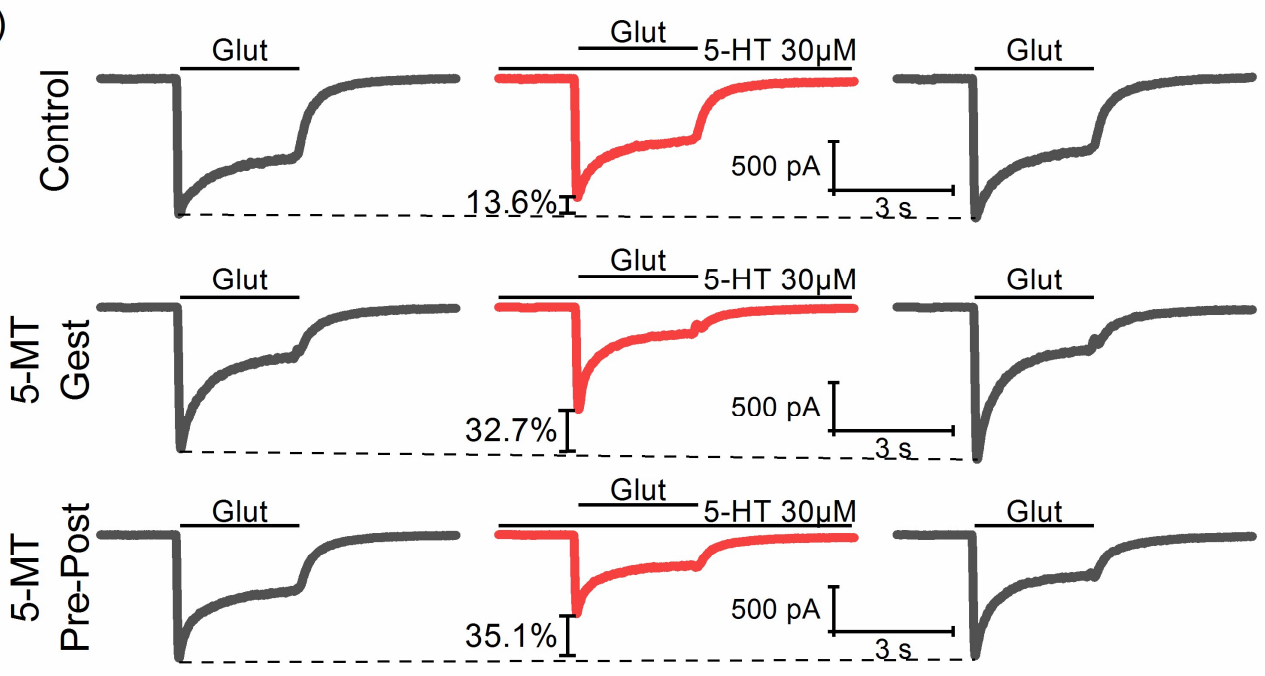

Figure 2. Comparison of the effect of different 5-methoxytryptamine (5-MT) administration times on $\mathrm{I}_{\mathrm{Glut}}$ in the presence of serotonin (5-HT). We conducted a one-way between-groups ANOVA to compare the effect on $\mathrm{I}_{\mathrm{Glut}}(100 \mu \mathrm{M})$ peak amplitude $(\mathbf{A})$ and SS (B) on the presence of 5-HT $(30 \mu \mathrm{M})$ in the groups of treatment 5-MT Gest (GD11-GD21; $n=10)$, 5-MT Pre-Post (GD11-PND21; $n=13$ ), and control $(n=12)$. Significant differences were found on both current components (Peak amplitude: $\mathrm{F}_{2,32}$ $=16.18 ; p<0.001$. SS: $\mathrm{F}_{2,32}=17.88 ; p<0.001$ ) for both treated groups from the control but not between them. (C) Representative traces of $\mathrm{I}_{\mathrm{Glut}}$ in the presence and absence of 5-HT from pyramidal neurons from each group tested. Significant differences among groups are indicated according to the following significance code: $\left.p<0.001{ }^{(* *}\right), p<0.01\left(^{* *}\right), p<0.05\left(^{*}\right)$. 
Table 1. Post-hoc comparisons among groups using the Tukey test $(p<0.05)$.

\begin{tabular}{c|ccccccccc}
\hline & \multicolumn{3}{c}{ Peak Amplitude Inhibition (\%) } & \multicolumn{3}{c}{ Steady-State Inhibition (\%) } \\
\hline & MeanDiff & SEM & q Value & $p(<|q|)$ & MeanDiff & SEM & q Value & $p(<|q|)$ \\
\hline 5-MT Gest Vs. Control & 14.73 & 3.72 & 5.6 & $* *$ & 15.91 & 3.79 & 5.94 & $* * *$ \\
5-MT Pre-Post Vs. Control & 19.10 & 3.48 & 7.77 & $* * *$ & 20.41 & 3.54 & 8.15 & $* * *$ \\
5-MT Pre-Post Vs. 5-MT Gest & 4.37 & 3.65 & 1.69 & ns. & 4.50 & 3.72 & 1.71 & ns. \\
\hline
\end{tabular}

Significance codes: $p<0.001\left(^{* * *}\right), p<0.01\left(^{* *}\right), p<0.05\left(^{*}\right), p>0.05$ (ns.)

\subsection{5-HT Reduces the NMDA Receptor-Mediated Component of $I_{G l u t}$}

As GD11-GD21 treatment showed no difference from treatment continued up to PND21, we chose to focus on the former to study how altering the mother's serotonergic system at a critical period of offspring development can produce lifelong changes in them. Thus, we analyzed the 5-HT $(30 \mu \mathrm{M})$ effect on both peak amplitude and SS of $\mathrm{I}_{\text {Glut }}(100 \mu \mathrm{M})$ for control and 5-MT Gest groups (Control, $n=9$; 5-MT Gest, $n=9$ ). We observed that the peak amplitude shows inhibition of $12.08 \pm 1.75 \%$ in the control group, and $24.48 \pm 2.46 \%$ in those offspring from treated mothers, while the SS was reduced $18.83 \pm 3.32 \%$ and $32.14 \pm 4.03 \%$, respectively. The difference between groups was significant in both parameters (Peak, $\mathrm{t}_{14.43}=4.108, p=0.001 ; \mathrm{SS}, \mathrm{t}_{15.44}=2.55, p=0.02$ ). During the same protocol, we perfused the cell with $\mathrm{Mg}^{++}(1 \mathrm{mM})$, a known NMDA blocker in order to study the remaining glutamate current and the effect of 5-HT on it. In this way $\mathrm{Mg}^{++}$alone reduced the peak amplitude by $94.01 \pm 1.09 \%$ for the control group and $94.68 \pm 0.82 \%$ for the treated one, while the SS reduced by $91.31 \pm 2.22 \%$ and $91.04 \pm 0.97 \%$ respectively (Figure 3 ), showing no significant difference between the groups (Peak, $\mathrm{t}_{14.94}=0.49, p=0.63 ; \mathrm{SS}, \mathrm{t}_{10.92}=-0.11, p=0.911$ ). Similarly, when $\mathrm{Mg}^{++}$was co-applied with 5-HT, neither peak amplitude (Control: $94.35 \pm 0.92$; 5-MT Gest: $94.74 \pm 0.95)$ nor SS (Control: $92.38 \pm 1.87$; 5-MT Gest: $91.95 \pm 0.82$ ) showed significant differences (Peak: $t_{15.99}=0.29, p=0.78$; SS: $\left.\mathrm{t}_{10.92}=-0.21, p=0.84\right)$. It should be noted that no difference was found between the presence and absence of $\mathrm{Mg}^{++}$for the same group in either peak amplitude (Control: $\mathrm{t}_{15.59}=-0.24, p=0.82$; 5-MT Gest: $\mathrm{t}_{15.71}=-0.04, p=0.97$ ) or SS (Control: $\mathrm{t}_{15.56}=-0.36, p=0.72 ; 5$-MT Gest: $\mathrm{t}_{15.56}=-0.72$, $p=0.48$ ). In summary, the above suggests that treatment with 5-MT causes an increase of up to twice the inhibitory effect of 5-HT over the entire current, mainly affecting the modulation of the NMDA receptor-mediated component of $\mathrm{I}_{\mathrm{Glut}}$.

To verify that the $\mathrm{I}_{\text {Glut }}$ component affected by treatment was NMDA receptor-mediated, we compared $\mathrm{I}_{\mathrm{Glut}}$ and $\mathrm{I}_{\mathrm{NMDA}}$ in the presence of 5-HT in the same cell. 5-MT treatment caused a significant increase of the 5-HT inhibitory effect on the peak amplitude of both $\mathrm{I}_{\text {Glut }}\left(\mathrm{t}_{-3.52}=7.64, p=0.008\right)$ and $\mathrm{I}_{\text {NMDA }}\left(\mathrm{t}_{-3.74}=8.15, p=0.005\right)$ relative to the control group. Similarly, the serotonergic inhibition of SS was increased on both currents by the treatment $\left(\mathrm{I}_{\text {Glut }}: \mathrm{t}_{6.43}=-2.59, p=0.04 ; \mathrm{I}_{\mathrm{NMDA}}: \mathrm{t}_{5.09}=-3.07, p=\right.$ 0.02). When $5-\mathrm{HT}(30 \mu \mathrm{M})$ was present in the solution, $\mathrm{I}_{\mathrm{Glut}}(100 \mu \mathrm{M})$ reduced $20.88 \pm 5.01 \%$ of the peak amplitude and $29.90 \pm 6.04$ of the SS in the control group, while in the 5-MT Gest group, the reduction was $42.73 \pm 3.65 \%$ and $47.87 \pm 3.41$, respectively. Similarly, $\mathrm{I}_{\mathrm{NMDA}}(100 \mu \mathrm{M})$ peak amplitude reduced $22.3 \pm 4.43 \%$ in the control group and $43.58 \pm 3.58 \%$ in the treated one, while SS reduced $29.02 \pm 6.57$ and $50.56 \pm 2.43$, respectively, in the presence of 5-HT (Figure 4). Additionally, the inhibition caused by $5-\mathrm{HT}$ in $\mathrm{I}_{\text {Glut }}$ and $\mathrm{I}_{\mathrm{NMDA}}$ in the same cell exhibits no statistically significant difference between them neither on peak amplitude (Control, $\mathrm{t}_{4}=0.52, p=0.63$; 5-MT Gest, $\mathrm{t}_{5}=0.24, p=0.82$ ) or SS (Control $\mathrm{t}_{4}$ $=-0.19, p=0.86 ; 5-\mathrm{MT} \mathrm{t}_{5}=0.7153, p=0.51$ ). That is, the treatment affects the 5-HT modulation of both $\mathrm{I}_{\mathrm{Glut}}$ and $\mathrm{I}_{\mathrm{NMDA}}$ in the same proportion. 

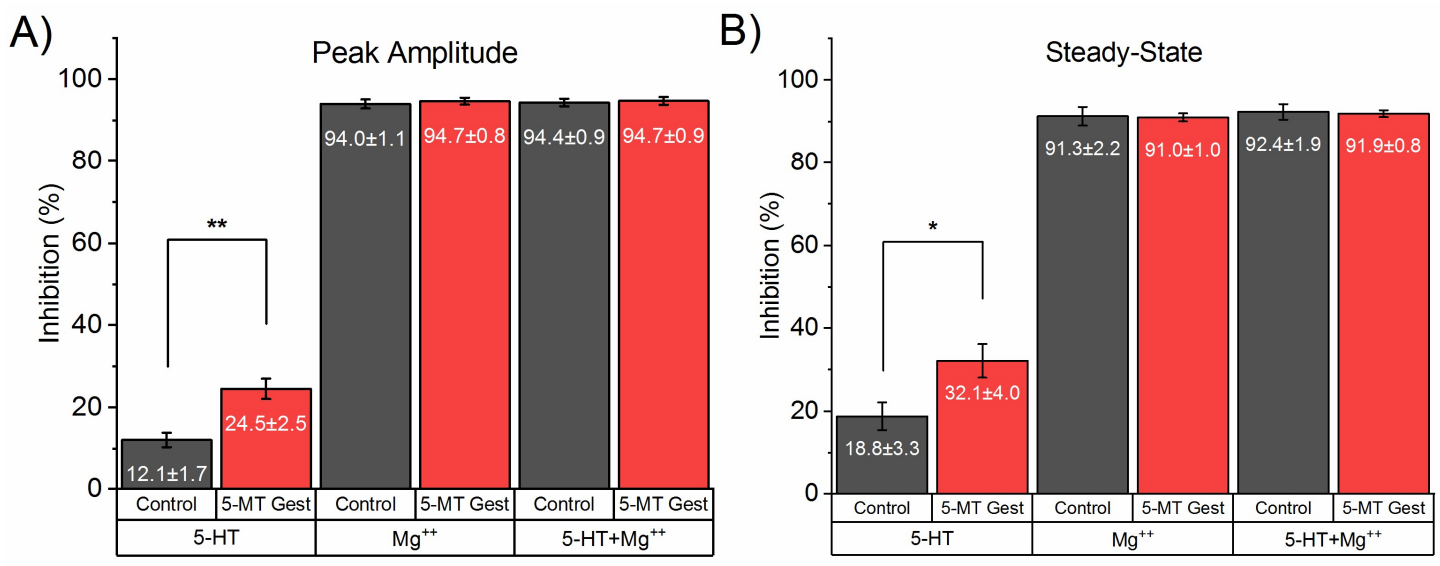

C)
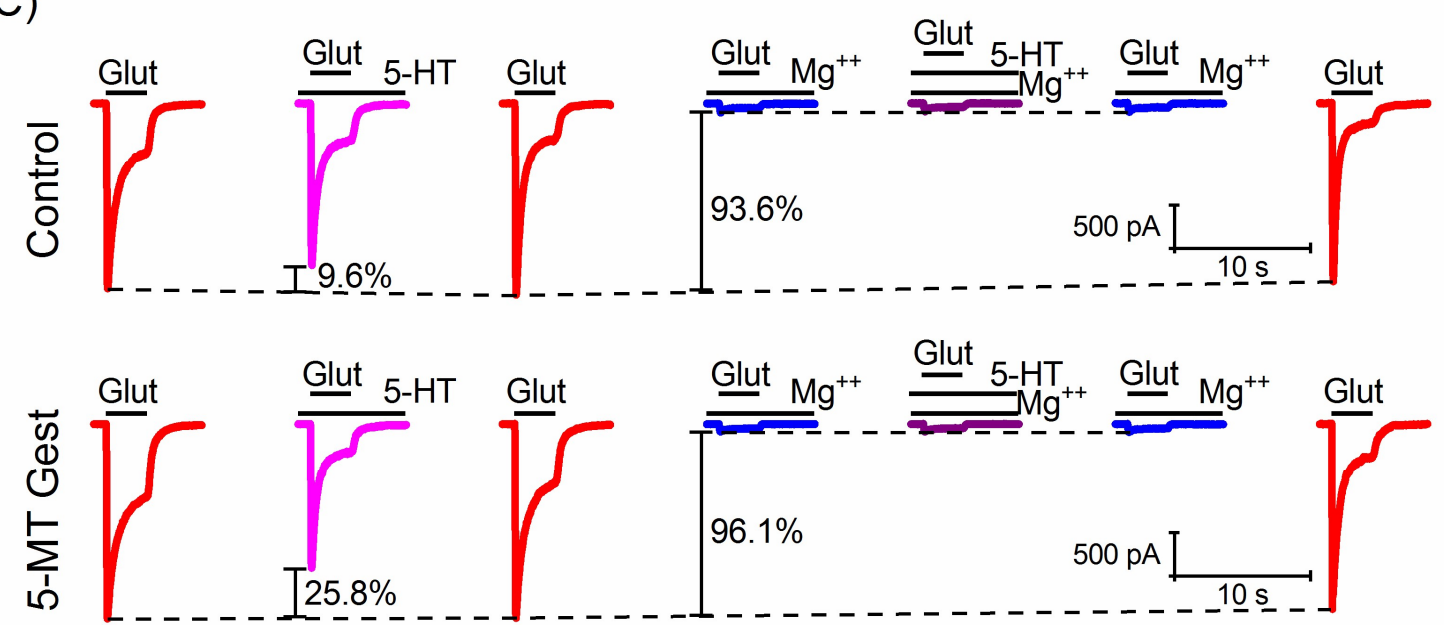

Figure 3. Effect of 5-HT $(30 \mu \mathrm{M})$ on both peak amplitude and SS of $\mathrm{I}_{\mathrm{Glut}}(100 \mu \mathrm{M})$ in the presence and absence of $\mathrm{Mg}^{++}(1 \mathrm{mM})$. Peak amplitude $(A)$ shows a significant difference $\left(\mathrm{t}_{14.43}=4.108, p=0.001\right)$ between inhibition of $12.08 \pm 1.75 \%$ in the control group $(n=9)$, and $24.48 \pm 2.46 \%$ in those offspring from treated mothers $(n=9)$ when cells were perfused with 5-HT $\left(\mathrm{t}_{14.43}=4.108, p=0.001\right)$, however, no differences were found between the groups when $\mathrm{Mg}^{++}$was applied $\left(\mathrm{t}_{14.94}=0.49, p=0.63\right)$ nor when $\mathrm{Mg}^{++}$and 5-HT were co-applied $\left(\mathrm{t}_{15.99}=0.29, p=0.78\right)$. Similarly, $\mathrm{SS}(\mathbf{B})$ shows difference between groups in the presence of 5-HT (Control: $18.83 \pm 3.32 \%$; 5 -MT Gest: $32.14 \pm 4.03 \%$; $\mathrm{t}_{15.44}=$ $2.55, p=0.02)$, but not when it was co-applied with $\mathrm{Mg}^{++}\left(\mathrm{t}_{10.92}=-0.21, p=0.84\right)$ or in the presence of $\mathrm{Mg}^{++}$alone $\left(\mathrm{t}_{10.92}=-0.11, p=0.91\right)$. Also no difference was found between the presence and absence of $\mathrm{Mg}^{++}$within the same group in either peak amplitude (Control: $\mathrm{t}_{15.59}=-0.24, p=0.82$; 5-MT Gest: $\mathrm{t}_{15.71}=-0.04, p=0.97$ ) or SS (Control: $\mathrm{t}_{15.56}=-0.36, p=0.72 ; 5-\mathrm{MT}$ Gest: $\mathrm{t}_{15.56}=-0.72, p=0.48$ ).

(C) Representative traces of $\mathrm{I}_{\mathrm{Glut}}$ in the presence and absence of $5-\mathrm{HT}$ or $\mathrm{Mg}^{++}$and when co-applied.

Significance codes: $\left.p<0.001\left(^{* * *}\right), p<0.01{ }^{* *}\right), p<0.05\left(^{*}\right)$.

Once we identified that the NMDA receptor-mediated current was the $\mathrm{I}_{\text {Glut }}$ component mainly affected by the treatment, we wanted to verify that the observed changes were due to alterations in 5-HT modulation of the current and not in the $\mathrm{I}_{\mathrm{NMDA}}$ itself. To do this, we made an NMDA dose-response curve from 0.3 to $300 \mu \mathrm{M}$ in both groups. We analyzed the peak amplitude and SS of currents from each concentration (Table 2), then fitted data to a logistic curve (Figure 5) and compared them with an F-test. No significant differences were found between groups on peak $\left(\mathrm{F}_{4,119}=1.98, p=0.10\right)$ or $\mathrm{SS}$ $\left(\mathrm{F}_{4,119}=0.99, p=0.42\right)$. 
A)

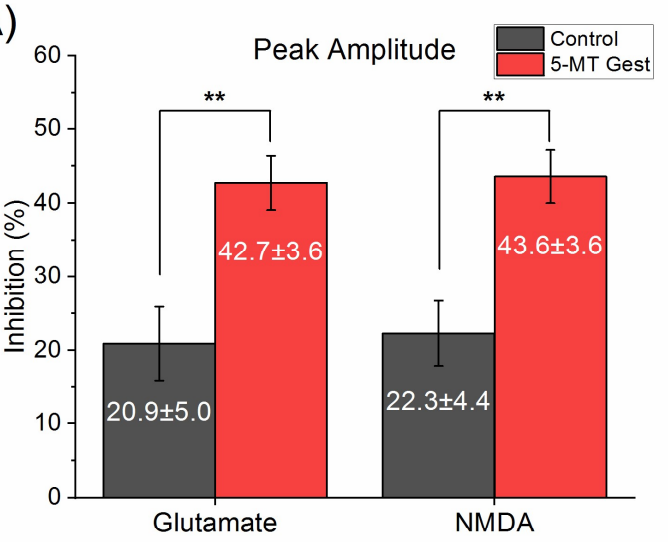

B)

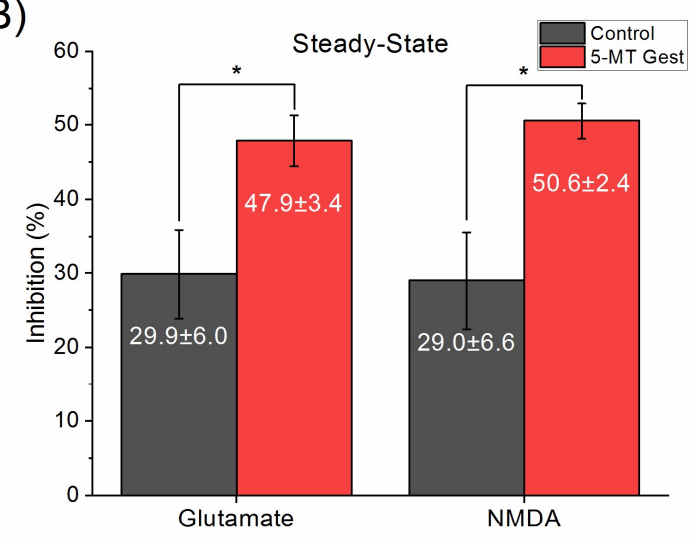

C)
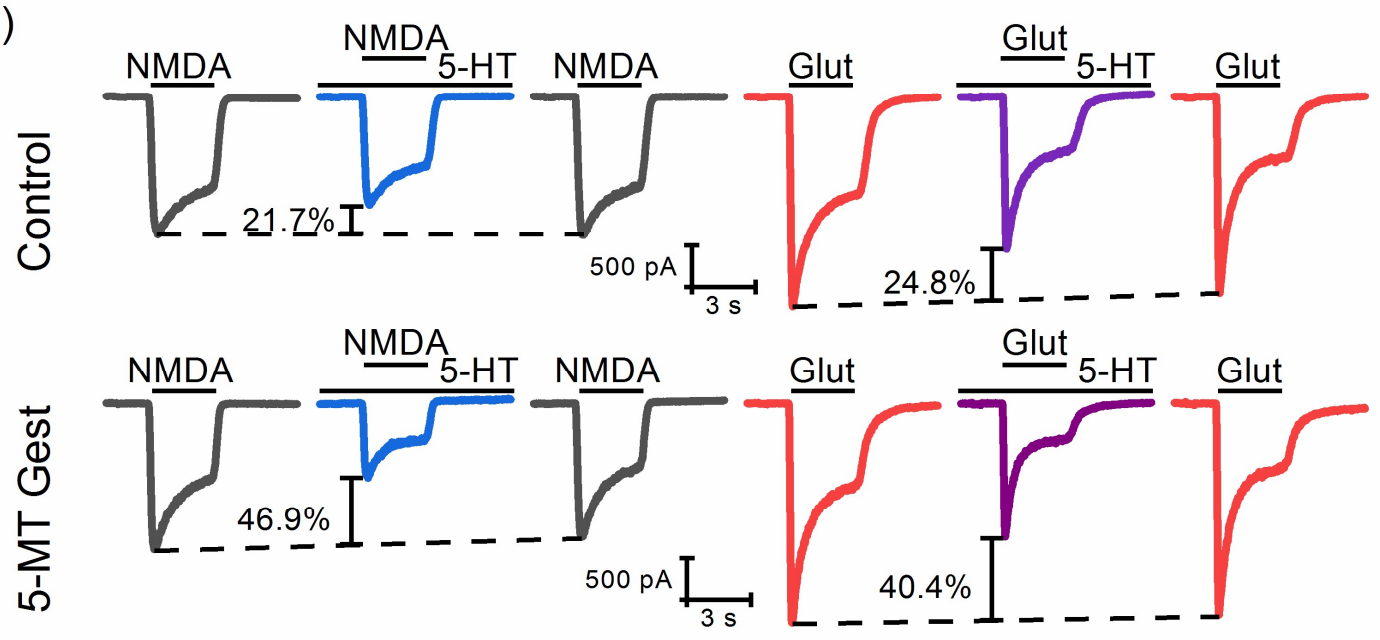

Figure 4. Effect of 5-HT $(30 \mu \mathrm{M})$ on $\mathrm{I}_{\text {Glut }}$ and $\mathrm{I}_{\mathrm{NMDA}}$. The 5-MT treatment caused a significant increase of the 5-HT inhibitory effect of the peak amplitude (A) of both $\mathrm{I}_{\mathrm{Glut}}\left(\mathrm{t}_{-3.52}=7.64, p=0.008\right)$ and $\mathrm{I}_{\mathrm{NMDA}}$ $\left(\mathrm{t}_{-3.74}=8.15, p=0.005\right)$ relative to the control group. The SS (B) presents a similar increase in both currents $\left(\mathrm{I}_{\mathrm{Glut}}: \mathrm{t}_{6.43}=-2.59, p=0.04 ; \mathrm{I}_{\mathrm{NMDA}}: \mathrm{t}_{5.09}=-3.07, p=0.02\right)$. Conversely, the inhibition caused by $5-\mathrm{HT}$ in $\mathrm{I}_{\mathrm{Glut}}$ and $\mathrm{I}_{\mathrm{NMDA}}$ in the same cell presents no statistically significant difference between them neither on peak amplitude (Control, $\mathrm{t}_{4}=0.52, p=0.63$; 5-MT Gest, $\mathrm{t}_{5}=0.24, p=0.82$ ) or SS (Control $\mathrm{t}_{4}$ $=-0.19, p=0.86$; 5 -MT $\mathrm{t}_{5}=0.7153, p=0.51$ ). (C) Representative traces of $\mathrm{I}_{\mathrm{Glut}}$ and $\mathrm{I}_{\mathrm{NMDA}}$ both in the presence and absence of 5-HT in the same cell. Significance codes: $p<0.001\left(^{(* *}\right), p<0.01\left(^{* *}\right), p<0.05\left(^{*}\right)$.

Table 2. Peak amplitude and steady-state of currents from each NMDA concentration.

\begin{tabular}{ccccc}
\hline NMDA $(\mu \mathrm{M})$ & \multicolumn{2}{c}{ Peak Amplitude $(\mathbf{p A} / \mathbf{p F})$} & \multicolumn{2}{c}{ Steady-State $(\mathbf{p A} / \mathbf{p F})$} \\
\hline & Control & 5-MT Gest & Control & 5-MT Gest \\
\hline $\mathbf{0 . 3}$ & $-0.95 \pm 0.20(9)$ & $-0.71 \pm 0.11(7)$ & $-0.25 \pm 0.13(9)$ & $-0.26 \pm 0.08(7)$ \\
$\mathbf{1}$ & $-1.34 \pm 0.30(9)$ & $-0.95 \pm 0.19(9)$ & $-0.41 \pm 0.27(9)$ & $-0.52 \pm 0.13(9)$ \\
$\mathbf{3}$ & $-3.05 \pm 0.38(8)$ & $-2.95 \pm 0.40(9)$ & $-2.13 \pm 0.37(8)$ & $-2.24 \pm 0.38(9)$ \\
$\mathbf{1 0}$ & $-9.26 \pm 0.97(9)$ & $-7.61 \pm 0.88(9)$ & $-6.47 \pm 1.00(9)$ & $-5.12 \pm 0.84(9)$ \\
$\mathbf{3 0}$ & $-31.85 \pm 3.08(9)$ & $-26.74 \pm 2.22(9)$ & $-19.42 \pm 2.76(9)$ & $-14.90 \pm 1.95(9)$ \\
$\mathbf{1 0 0}$ & $-61.18 \pm 4.27(9)$ & $-55.34 \pm 6.05(9)$ & $-25.25 \pm 4.36(9)$ & $-24.54 \pm 5.00(9)$ \\
$\mathbf{3 0 0}$ & $-80.80 \pm 3.88(9)$ & $-72.21 \pm 6.24(9)$ & $-26.11 \pm 4.35(9)$ & $-26.20 \pm 5.57(9)$ \\
\hline
\end{tabular}

The number of recorded cells for each NMDA concentration and group are displayed between the parentheses. 
A)

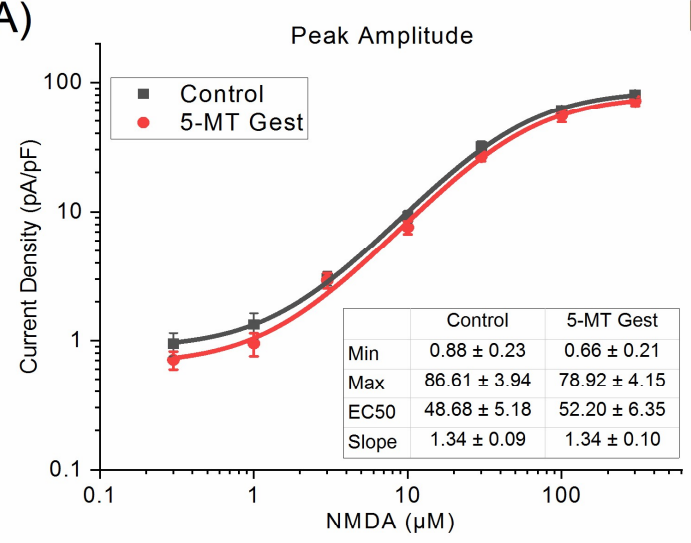

C)

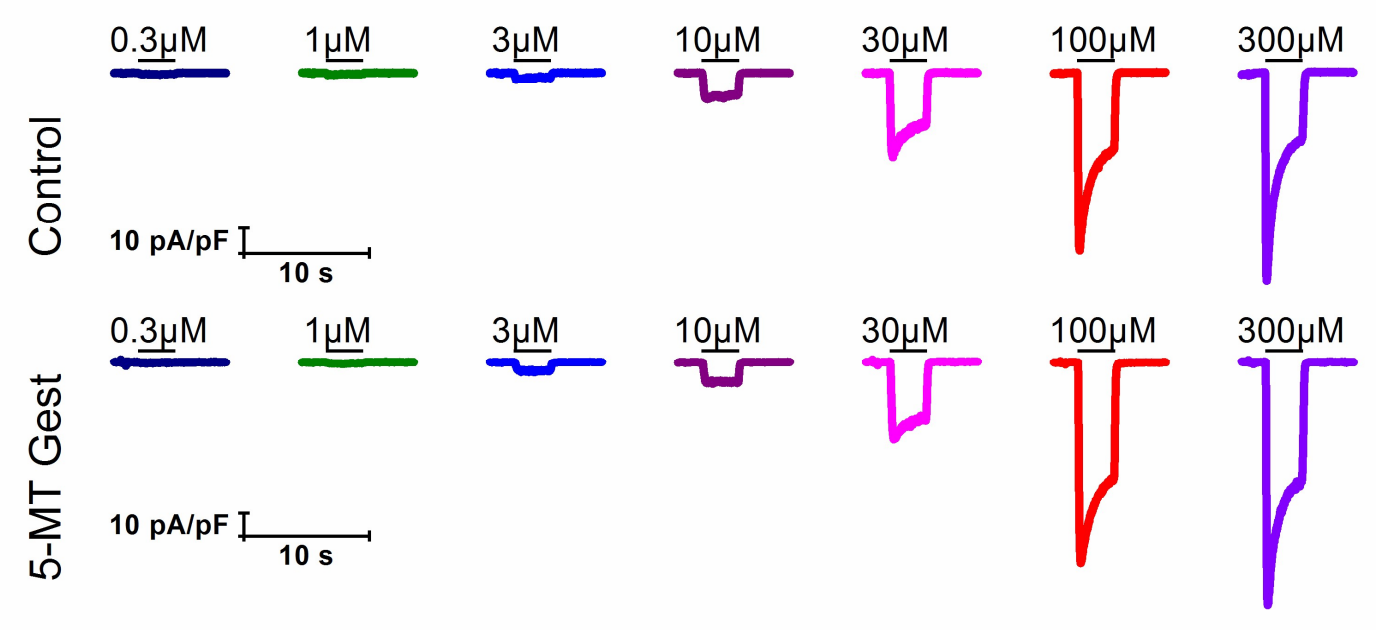

B)

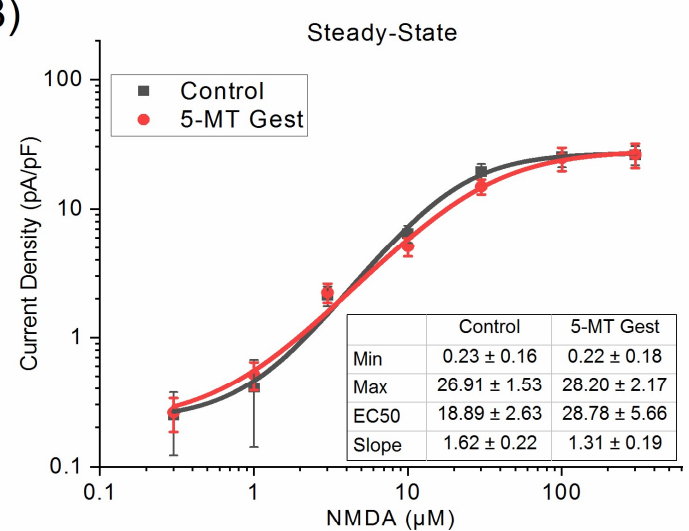

Figure 5. NMDA dose-response curve from 0.3 to $300 \mu \mathrm{M}$ in both groups. We analyzed the peak amplitude (A) and SS (B) of currents from each concentration, then fitted the data with a logistic function (solid lines) and compared the fitting curves with an F-test. No significant differences were found between groups (peak amplitude: $\mathrm{F}_{4,119}=1.98, p=0.10$; SS: $\mathrm{F}_{4,119}=0.99, p=0.42$ ). (C) Representative traces of $\mathrm{I}_{\mathrm{NMDA}}$ for each tested concentration on both groups.

\subsection{5-MT Treatment Increases the Modulatory Effect of 5-HT on $I_{N M D A}$}

Subsequently, since we did not find differences between groups in $\mathrm{I}_{\mathrm{NMDA}}$, we made a dose-response curve for the effect of 5-HT (ranged from 1 to $100 \mu \mathrm{M})$ in the $\mathrm{I}_{\mathrm{NMDA}}(100 \mu \mathrm{M})$. For this curve, we used a total of 54 cells, 33 for the control group, and 21 for the treatment group, each exposed to a maximum of three concentrations of 5-HT administered in random order. The peak amplitude and SS were analyzed (Table 3), itted to a logistic curve with minimum value fixed to zero (Figure 6), and then compared with an F-test. In this way, we found a statistically significant difference between groups in both peak amplitude $\left(\mathrm{F}_{3,125}=10.36, p<0.001\right)$ and $\mathrm{SS}\left(\mathrm{F}_{3,125}=4.23, p=0.007\right)$. Also, the difference between groups for each concentration was measured, finding a significant increase of 5-HT inhibition of $\mathrm{I}_{\mathrm{NMDA}}$ in treated group related to the control, in $30 \mu \mathrm{M}\left(\mathrm{t}_{25.57}=-4.42, p<0.001\right)$ and $100 \mu \mathrm{M}\left(\mathrm{t}_{23.01}=-2.33, p=0.03\right)$ for peak amplitude, and $1 \mu \mathrm{M}\left(\mathrm{t}_{15.48}=-2.88, p=0.01\right), 30 \mu \mathrm{M}\left(\mathrm{t}_{26.74}=\right.$ $-2.07, p=0.048)$, and $100 \mu \mathrm{M}\left(\mathrm{t}_{22.14}=-2.18, p=0.04\right)$ for SS. 
A)

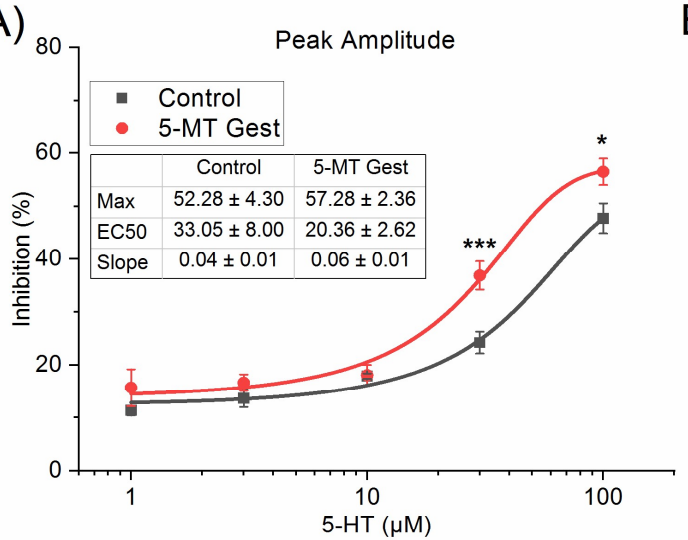

B)

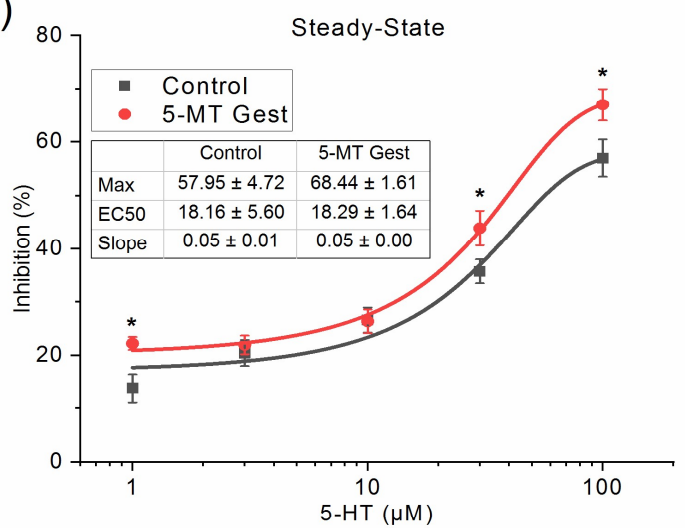

C)

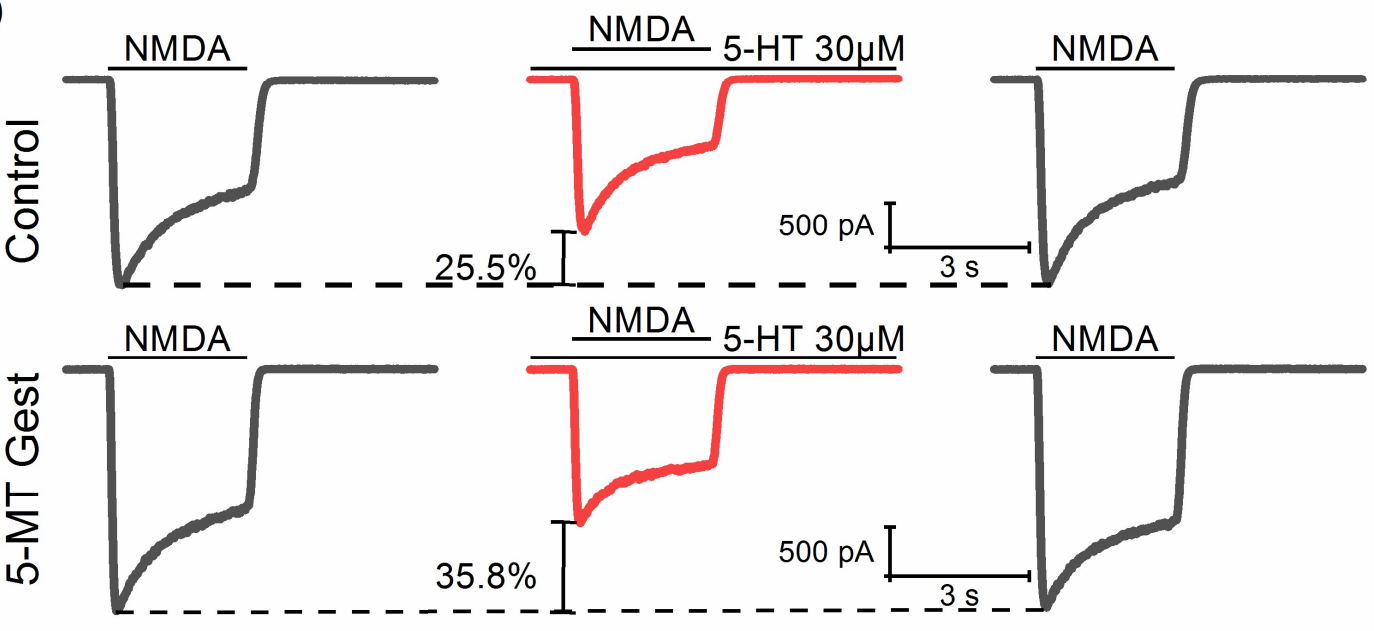

Figure 6. Dose-response curve for the effect of 5-HT from 1 to $100 \mu \mathrm{M}$ in the $\mathrm{I}_{\mathrm{NMDA}}(100 \mu \mathrm{M})$. As with the NMDA dose-response, data were analyzed, fitted (solid lines), and compared with an F-test. In this way, we found significant differences between groups in both the peak amplitude $\left(\mathbf{A} ; \mathrm{F}_{3,125}=10.36, p<\right.$ $0.001)$ and the steady-state $\left(\mathbf{B}, \mathrm{F}_{3,125}=4.23, p=0.007\right)$. Also, the difference between groups for each concentration was measured, finding significance in $30 \mu \mathrm{M}(\mathrm{t} 25.57=-4.42, p<0.001)$ and $100 \mu \mathrm{M}$ $(\mathrm{t} 23.01=-2.33, p=0.03)$ for peak amplitude, and $1 \mu \mathrm{M}(\mathrm{t} 15.48=-2.88, p=0.01), 30 \mu \mathrm{M}(\mathrm{t} 26.74=$ $-2.07, p=0.048)$, and $100 \mu \mathrm{M}(\mathrm{t} 22.14=-2.18, p=0.04)$ for SS. (C) Representative traces of $\mathrm{I}_{\mathrm{NMDA}}$ in the presence and absence of 5-HT $30 \mu \mathrm{M}$. Significance codes: $p<0.001\left(^{* * *}\right), p<0.01\left({ }^{* *}\right), p<0.05\left(^{*}\right)$.

Table 3. Comparison between groups of the percentage inhibition of the peak amplitude and steady-state of the $\mathrm{I}_{\mathrm{NMDA}}$ for each 5-HT concentration.

\begin{tabular}{c|cccccc}
\hline 5-HT $(\mu \mathrm{M})$ & \multicolumn{2}{c}{ Peak Amplitude Inhibition (\%) } & \multicolumn{2}{c}{ Steady-State Inhibition (\%) } \\
\hline & Control & 5-MT Gest & $p(<|\mathbf{t}|)$ & Control & 5-MT Gest & $p(<|\mathbf{t}|)$ \\
\hline 1 & $11.33 \pm 0.90(13)$ & $15.68 \pm 3.51(7)$ & ns. & $13.73 \pm 2.69(13)$ & $22.24 \pm 1.22(7)$ & $*$ \\
3 & $13.64 \pm 1.65(9)$ & $16.63 \pm 1.57(13)$ & ns. & $20.44 \pm 2.45(9)$ & $21.97 \pm 1.73(13)$ & ns. \\
10 & $17.88 \pm 0.50(14)$ & $18.05 \pm 1.94(11)$ & ns. & $26.64 \pm 2.33(14)$ & $26.38 \pm 2.23(11)$ & ns. \\
30 & $24.23 \pm 2.06(16)$ & $36.92 \pm 2.69(16)$ & $* *$ & $35.77 \pm 2.29(16)$ & $46.94 \pm 3.29(16)$ & $*$ \\
100 & $47.75 \pm 2.81(12)$ & $56.51 \pm 2.48(14)$ & $*$ & $56.99 \pm 3.48(12)$ & $66.98 \pm 2.98(14)$ & $*$ \\
\hline
\end{tabular}

The number of recorded cells for each 5-HT concentration and group are displayed between the parentheses. Significance codes: $p<0.001\left(^{(* *)}, p<0.01\left(^{* *}\right), p<0.05\left(^{*}\right), p>0.05\right.$ (ns.).

\section{Discussion}

This study aims to evaluate the effect of 5-HT on $\mathrm{I}_{\mathrm{NMDA}}$ and $\mathrm{I}_{\text {Glut }}$ in dissociated pyramidal neurons of PFC layer V-VI in the offspring of rats treated with a 5-HT agonist during pregnancy. Our data showed that offspring from dams treated with the serotonergic agonist 5-MT (sc. $1 \mathrm{mg} / \mathrm{kg} /$ day) from GD11 to 
G21 presents significant differences on peak amplitude and SS of $\mathrm{I}_{\mathrm{Glut}}$ in the presence of 5-HT relative to the control group, but did not show differences with treatment continued up to PND21. Observed differences in $\mathrm{I}_{\mathrm{Glut}}$ in the presence of 5-HT are due to an inhibition of the NMDA receptor-activated component of $\mathrm{I}_{\text {Glut }}$. Nonetheless, $\mathrm{I}_{\mathrm{NMDA}}$ itself is not affected except for its serotonergic modulation. In particular, on the 5-HT dose-response curve, an increase in the inhibitory effect of 5-HT on I NMDA was observed, with significant differences of 30 and $100 \mu \mathrm{M}$ for both peak amplitude and SS.

Our work reaffirms the notion that the effect of 5-HT on PFC pyramidal neurons is mainly inhibitory, and further provides evidence that this inhibitory effect modulates the NMDA-activated component of the $\mathrm{I}_{\mathrm{Glut}}$. After mimicking a rise in 5-HT concentration with 5-MT, we found an increase of the inhibitory effect of 5-HT, even when the agonist was administered from G11 to birth, or if the treatment was continued until PND21. This increase in the inhibitory effect of 5-HT could lead to a decrease in the excitability of pyramidal neurons in the PFC, similar to what Robello et al. [44] found in the infralimbic cortex, after treatment with a SERT antagonist from PND2 to PND21. Robello et al. [44] found an increase in the excitability of pyramidal neurons from the prelimbic cortex; conversely, we did not find any modulation that could reproduce such a response. The difference in treatment period and layers analyzed could explain the discrepancy between both studies, and it could be due to the different expression and distribution of the 5-HT receptors over time, layers, and subfields of the PFC [24,63].

Animal models using 5-MT to mimic an increase of 5-HT concentration during development have found numerous abnormalities in the serotonergic system $[39,67,68]$, the oxytocinergic cell density [39,69], as well as behavioral [70,71] and morphological changes [43] that have been proposed to be involved in the genesis of multiple neuropsychiatric disorders.

An example of the abnormalities explained above is the autism spectrum, which is the result of an increased 5-HT concentration to which the fetus is exposed during development, a hypothesis described by Whitaker-Azmitia [59] and which provides the basis for the development of her DHS model for autism [59]. However, this hypothesis is based mainly on behavioral evidence [59,70,71]. Therefore, our work examines mechanisms in ionic currents and their modulation, thus supporting this hypothesis. Moreover, our findings shed light on the critical time window and underlying changes involved in this disorder for future study.

Another theory, described by Carlson M.L. [72], postulates that autism could be a hypoglutamatergic disorder; this is based on neuroanatomical and neuroimaging studies indicating alterations in regions rich in glutamatergic neurons, as well as the similarity of symptoms observed in autism and those produced by NMDA antagonists in healthy subjects. In support of this theory, variations of the gene encoding the GluN2B subunit, which does not allow for adequate trafficking and expression to the cell surface, have recently been found in some autistic and schizophrenic patients [73,74]. Concerning this, Yuen et al. [75] demonstrated that activation of the $5-\mathrm{HT}_{1 \mathrm{~A}}$ receptor decreases the traffic and expression of the GluN2B subunit. Therefore, an increase in serotonergic activity, as found in our work, could be contributing through an exacerbation of this mechanism in the development of autism and other disorders.

Altered concentrations of other neurotransmitters, such as dopamine and acetylcholine, have also been associated with the development of disorders such as depression and schizophrenia [76-80]. Therefore, experiments performed with these modulators could provide correlates in the modulation of ionic currents following gestational disturbances, which will be addressed on future work. In this sense, our work is a pioneer in the study of the modulation of ionic currents after variations in the concentration of modulators to which the offspring's brain is exposed during the gestational period.

Our results are consistent with previous studies showing that prenatal exposure to morphine alters the kinetic properties of $\mathrm{I}_{\mathrm{NMDA}}$ currents in the hippocampus of the rat offspring [81]. In this context, it is possible that the prenatal exposure to any drug alters the neuromodulator actions on $\mathrm{I}_{\mathrm{NMDA}}$ and $\mathrm{I}_{\mathrm{Glut}}$, as well as other ligand-gated channels, in a variety of neurons from the offspring's brain. 


\section{Conclusions}

The gestational treatment with a neuromodulator, 5-MT, induces changes in its modulatory function on glutamate currents during adulthood of the offspring. As this increase in modulators, in our case serotonin, can be produced by strong emotional states in certain periods of the gestation this alteration can lead to changes in the way to process information and can be related with pathological psychiatric disorders.

Author Contributions: Conceptualization, G.H.-C. and J.F.-H.; methodology, G.H.-C., E.A.R.-L., and G.L.-L.; software, G.H.-C.; validation, G.L.-L.; formal analysis, G.H.-C. and E.A.R.-L.; investigation, G.H.-C. and E.A.R.-L.; resources, J.F.-H.; data curation, G.H.-C., E.A.R.-L., and G.L.-L.; writing-original draft preparation, G.H.-C.; writing - review and editing, E.M. and J.F.-H.; visualization, G.H.-C. and J.F.-H.; supervision, E.M. and J.F.-H.; project administration, J.F.-H.; funding acquisition, J.F.-H. All authors have read and agreed to the published version of the manuscript.

Funding: This research was funded by VIEP (VIEP/1944/2016) and CONACyT (441033) grants to G.H.-C, and from Catedra Marcos Moshisky to E.M.

Conflicts of Interest: The authors declare no conflict of interest.

\section{References}

1. Beyond Neurotransmission: Neuromodulation and Its Importance for Information Processing, 1st ed.; Katz, P.S., Ed.; Oxford University Press: New York, NY, USA, 1999; ISBN 978-0-19-852424-3.

2. Kupfermann, I. Modulatory actions of neurotransmitters. Annu. Rev. Neurosci. 1979, 2, 447-465. [CrossRef]

3. Levitan, I.B. Modulation of ION channels in neurons and other cells. Annu. Rev. Neurosci. 1988, 11, 119-136. [CrossRef]

4. Lopez, H.S.; Brown, A.M. Neuromodulation. Curr. Opin. Neurobiol. 1992, 2, 317-322. [CrossRef]

5. Marder, E.; Thirumalai, V. Cellular, synaptic and network effects of neuromodulation. Neural Netw. 2002, 15, 479-493. [CrossRef]

6. Nadim, F.; Bucher, D. Neuromodulation of neurons and synapses. Curr. Opin. Neurobiol. 2014, 29 , 48-56. [CrossRef]

7. Zoli, M.; Agnati, L.F. Wiring and volume transmission in the central nervous system: The concept of closed and open synapses. Prog. Neurobiol. 1996, 49, 363-380. [CrossRef]

8. Cassel, J.-C. Experimental studies on the role(s) of serotonin in learning and memory functions. In Handbook of Behavioral Neuroscience; Müller, C.P., Jacobs, B.L., Eds.; Handbook of the Behavioral Neurobiology of Serotonin; Elsevier: Amsterdam, The Netherlands, 2010; Volume 21, pp. 429-447.

9. Duman, E.A.; Canli, T. Social behavior and serotonin. In Handbook of Behavioral Neuroscience; Jacobs, C.P.M.B.L., Ed.; Handbook of the Behavioral Neurobiology of Serotonin; Elsevier: Amsterdam, The Netherlands, 2010; Volume 21, pp. 449-456.

10. Hensler, J.G. Serotonin in mood and emotion. In Handbook of Behavioral Neuroscience; Jacobs, C.P.M.B.L., Ed.; Handbook of the Behavioral Neurobiology of Serotonin; Elsevier: Amsterdam, The Netherlands, 2010; Volume 21, pp. 367-378.

11. Aghajanian, G.K.; Marek, G.J. Serotonin model of schizophrenia: Emerging role of glutamate mechanisms. Brain Res. Brain Res. Rev. 2000, 31, 302-312. [CrossRef]

12. Albert, P.R.; Vahid-Ansari, F.; Luckhart, C. Serotonin-prefrontal cortical circuitry in anxiety and depression phenotypes: Pivotal role of pre- and post-synaptic 5-HT1A receptor expression. Front. Behav. Neurosci. 2014, 8, 199. [CrossRef]

13. Eggers, A.E. A serotonin hypothesis of schizophrenia. Med. Hypotheses 2013, 80, 791-794. [CrossRef]

14. Lin, S.-H.; Lee, L.-T.; Yang, Y.K. Serotonin and mental disorders: A concise review on molecular neuroimaging evidence. Clin. Psychopharmacol. Neurosci. 2014, 12, 196-202. [CrossRef]

15. Ben-Ari, Y. Neuropaediatric and neuroarchaeology: Understanding development to correct brain disorders. Acta Paediatr. 2013, 102, 331-334. [CrossRef] [PubMed]

16. Frederick, A.L.; Stanwood, G.D. Drugs, biogenic amine targets and the developing brain. DNE 2009, 31, 7-22. [CrossRef] [PubMed] 
17. Herlenius, E.; Lagercrantz, H. Development of neurotransmitter systems during critical periods. Exp. Neurol. 2004, 190, 8-21. [CrossRef]

18. Ruediger, T.; Bolz, J. Neurotransmitters and the development of neuronal circuits. In Axon Growth and Guidance; Advances in Experimental Medicine and, Biology; Bagnard, D., Ed.; Springer: New York, NY, USA, 2007; pp. 104-114. ISBN 978-0-387-76715-4.

19. Sundström, E.; Kölare, S.; Souverbie, F.; Samuelsson, E.B.; Pschera, H.; Lunell, N.O.; Seiger, A. Neurochemical differentiation of human bulbospinal monoaminergic neurons during the first trimester. Brain Res. Dev. Brain Res. 1993, 75, 1-12. [CrossRef]

20. Lauder, J.M. Ontogeny of the serotonergic system in the rat: Serotonin as a developmental signal. Ann. N. Y. Acad. Sci. 1990, 600, 297-313, discussion 314. [CrossRef]

21. Rubenstein, J.L. Development of serotonergic neurons and their projections. Biol. Psychiatry 1998, 44, 145-150. [CrossRef]

22. Buznikov, G.A.; Lambert, W.H.; Lauder, J.M. Serotonin and serotonin-like substances as regulators of early embryogenesis and morphogenesis. Cell Tissue Res. 2001, 305, 177-186. [CrossRef]

23. Bonnin, A.; Goeden, N.; Chen, K.; Wilson, M.L.; King, J.; Shih, J.C.; Blakely, R.D.; Deneris, E.S.; Levitt, P. A transient placental source of serotonin for the fetal forebrain. Nature 2011, 472, 347-350. [CrossRef]

24. Booij, L.; Tremblay, R.E.; Szyf, M.; Benkelfat, C. Genetic and early environmental influences on the serotonin system: Consequences for brain development and risk for psychopathology. J. Psychiatry Neurosci. 2015, 40, 5-18. [CrossRef]

25. Brummelte, S.; Mc Glanaghy, E.; Bonnin, A.; Oberlander, T.F. Developmental changes in serotonin signaling: Implications for early brain function, behavior and adaptation. Neuroscience 2017, 342, 212-231. [CrossRef]

26. Gaspar, P.; Cases, O.; Maroteaux, L. The developmental role of serotonin: News from mouse molecular genetics. Nat. Rev. Neurosci. 2003, 4, 1002-1012. [CrossRef] [PubMed]

27. Oberlander, T.F. Fetal serotonin signaling: Setting pathways for early childhood development and behavior. J. Adolesc. Health 2012, 51, S9-S16. [CrossRef]

28. Whitaker-Azmitia, P.M. Serotonin and brain development: Role in human developmental diseases. Brain Res. Bull. 2001, 56, 479-485. [CrossRef]

29. Shah, R.; Courtiol, E.; Castellanos, F.X.; Teixeira, C.M. Abnormal serotonin levels during perinatal development lead to behavioral deficits in adulthood. Front. Behav. Neurosci. 2018, 12, 114. [CrossRef] [PubMed]

30. Suri, D.; Teixeira, C.M.; Cagliostro, M.K.C.; Mahadevia, D.; Ansorge, M.S. Monoamine-sensitive developmental periods impacting adult emotional and cognitive behaviors. Neuropsychopharmacology 2015, 40, 88-112. [CrossRef]

31. Vitalis, T.; Cases, O.; Passemard, S.; Callebert, J.; Parnavelas, J.G. Embryonic depletion of serotonin affects cortical development. Eur. J. Neurosci. 2007, 26, 331-344. [CrossRef]

32. González-Burgos, I.; Angel-Meza, A.R.D.; Barajas-López, G.; Feria-Velasco, A. Tryptophan restriction causes long-term plastic changes in corticofrontal pyramidal neurons. Int. J. Dev. Neurosci. 1996, 14, 673-679. [CrossRef]

33. Dooley, A.E.; Pappas, I.S.; Parnavelas, J.G. Serotonin promotes the survival of cortical glutamatergic neuronsin vitro. Exp. Neurol. 1997, 148, 205-214. [CrossRef]

34. Riccio, O.; Potter, G.; Walzer, C.; Vallet, P.; Szabó, G.; Vutskits, L.; Kiss, J.Z.; Dayer, A.G. Excess of serotonin affects embryonic interneuron migration through activation of the serotonin receptor 6. Mol. Psychiatry 2009, 14, 280-290. [CrossRef]

35. Riccio, O.; Jacobshagen, M.; Golding, B.; Vutskits, L.; Jabaudon, D.; Hornung, J.P.; Dayer, A.G. Excess of serotonin affects neocortical pyramidal neuron migration. Transl. Psychiatry 2011, 1, e47. [CrossRef]

36. Ansorge, M.S.; Morelli, E.; Gingrich, J.A. Inhibition of serotonin but not norepinephrine transport during development produces delayed, persistent perturbations of emotional behaviors in mice. J. Neurosci. 2008, 28, 199-207. [CrossRef] [PubMed]

37. Sprowles, J.L.N.; Hufgard, J.R.; Gutierrez, A.; Bailey, R.A.; Jablonski, S.A.; Williams, M.T.; Vorhees, C.V. Differential effects of perinatal exposure to antidepressants on learning and memory, acoustic startle, anxiety, and open-field activity in Sprague-Dawley rats. Int. J. Dev. Neurosci. 2017, 61, 92-111. [CrossRef] [PubMed] 
38. Lauder, J.M.; Liu, J.; Grayson, D.R. In utero exposure to serotonergic drugs alters neonatal expression of 5-HT(1A) receptor transcripts: A quantitative RT-PCR study. Int. J. Dev. Neurosci. 2000, 18, 171-176. [CrossRef]

39. Madden, A.M.K.; Zup, S.L. Effects of developmental hyperserotonemia on juvenile play behavior, oxytocin and serotonin receptor expression in the hypothalamus are age and sex dependent. Physiol. Behav. 2014, 128, 260-269. [CrossRef]

40. Blažević, S.; Hranilović, D. Expression of 5HT-related genes after perinatal treatment with 5HT agonists. Transl.Neurosci. 2013, 4, 165-171. [CrossRef]

41. Cases, O.; Vitalis, T.; Seif, I.; Maeyer, E.D.; Sotelo, C.; Gaspar, P. Lack of barrels in the somatosensory cortex of monoamine oxidase A-deficient mice: Role of a serotonin excess during the critical period. Neuron 1996, 16, 297-307. [CrossRef]

42. Vitalis, T.; Cases, O.; Callebert, J.; Launay, J.-M.; Price, D.J.; Seif, I.; Gaspar, P. Effects of monoamine oxidase A inhibition on barrel formation in the mouse somatosensory cortex: Determination of a sensitive developmental period. J. Comp. Neurol. 1998, 393, 169-184. [CrossRef]

43. Janušonis, S.; Gluncic, V.; Rakic, P. Early serotonergic projections to Cajal-Retzius cells: Relevance for cortical development. J. Neurosci. 2004, 24, 1652-1659. [CrossRef]

44. Rebello, T.J.; Yu, Q.; Goodfellow, N.M.; Cagliostro, M.K.C.; Teissier, A.; Morelli, E.; Demireva, E.Y.; Chemiakine, A.; Rosoklija, G.B.; Dwork, A.J.; et al. Postnatal day 2 to 11 constitutes a 5-HT-sensitive period impacting adult mPFC function. J. Neurosci. 2014, 34, 12379-12393. [CrossRef]

45. Fuster, J.M. The Prefrontal Cortex, 4th ed.; Elsevier: Amsterdam, The Netherlands, 2008; ISBN 978-0-12-373644-4.

46. Catts, V.S.; Fung, S.J.; Long, L.E.; Joshi, D.; Vercammen, A.; Allen, K.M.; Fillman, S.G.; Moore, L.; Rothmond, D.; Sinclair, D.; et al. Rethinking schizophrenia in the context of normal neurodevelopment. Front. Cell. Neurosci. 2013, 7, 60. [CrossRef]

47. Ghoshal, A.; Conn, P.J. The hippocampo-prefrontal pathway: A possible therapeutic target for negative and cognitive symptoms of schizophrenia. Futur. Neurol. 2015, 10, 115-128. [CrossRef] [PubMed]

48. Deserno, L.; Sterzer, P.; Wüstenberg, T.; Heinz, A.; Schlagenhauf, F. Reduced prefrontal-parietal effective connectivity and working memory deficits in schizophrenia. J. Neurosci. 2012, 32, 12-20. [CrossRef] [PubMed]

49. Garcia, L.P.; Witteveen, J.S.; Middelman, A.; van Hulten, J.A.; Martens, G.J.M.; Homberg, J.R.; Kolk, S.M. Perturbed developmental serotonin signaling affects prefrontal catecholaminergic innervation and cortical integrity. Mol. Neurobiol. 2019, 56, 1405-1420. [CrossRef] [PubMed]

50. Brumback, A.C.; Ellwood, I.T.; Kjaerby, C.; Iafrati, J.; Robinson, S.; Lee, A.T.; Patel, T.; Nagaraj, S.; Davatolhagh, F.; Sohal, V.S. Identifying specific prefrontal neurons that contribute to autism-associated abnormalities in physiology and social behavior. Mol. Psychiatry 2018, 23, 2078-2089. [CrossRef]

51. Willsey, A.J.; Sanders, S.J.; Li, M.; Dong, S.; Tebbenkamp, A.T.; Muhle, R.A.; Reilly, S.K.; Lin, L.; Fertuzinhos, S.; Miller, J.A.; et al. Coexpression networks implicate human midfetal deep cortical Projection neurons in the pathogenesis of autism. Cell 2013, 155, 997-1007. [CrossRef]

52. Goeden, N.; Velasquez, J.; Arnold, K.A.; Chan, Y.; Lund, B.T.; Anderson, G.M.; Bonnin, A. Maternal inflammation disrupts fetal neurodevelopment via increased placental output of serotonin to the fetal brain. J. Neurosci. 2016, 36, 6041-6049. [CrossRef]

53. Peters, D.A. Prenatal stress increases the behavioral response to serotonin agonists and alters open field behavior in the rat. Pharmacol. Biochem. Behav. 1986, 25, 873-877. [CrossRef]

54. Peters, D.A. Maternal stress increases fetal brain and neonatal cerebral cortex 5-hydroxytryptamine synthesis in rats: A possible mechanism by which stress influences brain development. Pharmacol. Biochem. Behav. 1990, 35, 943-947. [CrossRef]

55. St-Pierre, J.; Laurent, L.; King, S.; Vaillancourt, C. Effects of prenatal maternal stress on serotonin and fetal development. Placenta 2016, 48, S66-S71. [CrossRef]

56. Lattimore, K.A.; Donn, S.M.; Kaciroti, N.; Kemper, A.R.; Neal, C.R.; Vazquez, D.M. Selective Serotonin Reuptake Inhibitor (SSRI) use during pregnancy and effects on the fetus and newborn: A meta-analysis. J. Perinatol. 2005, 25, 595-604. [CrossRef]

57. Olivier, J.D.; Åkerud, H.; Kaihola, H.; Pawluski, J.L.; Skalkidou, A.; Högberg, U.; Sundström Poromaa, I. The effects of maternal depression and maternal selective serotonin reuptake inhibitor exposure on offspring. Front. Cell. Neurosci. 2013, 7, 73. [CrossRef] [PubMed] 
58. Velasquez, J.C.; Goeden, N.; Bonnin, A. Placental serotonin: Implications for the developmental effects of SSRIs and maternal depression. Front. Cell. Neurosci. 2013, 7, 47. [CrossRef] [PubMed]

59. Whitaker-Azmitia, P.M. Behavioral and cellular consequences of increasing serotonergic activity during brain development: A role in autism? Int. J. Dev. Neurosci. 2005, 23, 75-83. [CrossRef] [PubMed]

60. Bargas, J.; Howe, A.; Eberwine, J.; Cao, Y.; Surmeier, D.J. Cellular and molecular characterization of Ca2+ currents in acutely isolated, adult rat neostriatal neurons. J. Neurosci. 1994, 14, 6667-6686. [CrossRef] [PubMed]

61. Flores-Hernández, J.; Cepeda, C.; Hernández-Echeagaray, E.; Calvert, C.R.; Jokel, E.S.; Fienberg, A.A.; Greengard, P.; Levine, M.S. Dopamine enhancement of NMDA currents in dissociated medium-sized striatal neurons: Role of D1 receptors and DARPP-32. J. Neurophysiol. 2002, 88, 3010-3020. [CrossRef] [PubMed]

62. Flores-Hernández, J.; Hernandez, S.; Snyder, G.L.; Yan, Z.; Fienberg, A.A.; Moss, S.J.; Greengard, P.; Surmeier, D.J. D(1) dopamine receptor activation reduces GABA(A) receptor currents in neostriatal neurons through a PKA/DARPP-32/PP1 signaling cascade. J. Neurophysiol. 2000, 83, 2996-3004. [CrossRef]

63. Santana, N.; Artigas, F. Laminar and cellular distribution of monoamine receptors in rat medial prefrontal cortex. Front. Neuroanat. 2017, 11, 87. [CrossRef]

64. Parsons, C.G.; Danysz, W.; Hesselink, M.; Hartmann, S.; Lorenz, B.; Wollenburg, C.; Quack, G. Modulation of NMDA receptors by glycine - introduction to some basic aspects and recent developments. Amino Acids 1998, 14, 207-216. [CrossRef]

65. Ritz, C.; Baty, F.; Streibig, J.C.; Gerhard, D. Dose-response analysis using R. PLoS ONE 2015, 10, e0146021. [CrossRef]

66. R Core Team. R: A Language and Environment for Statistical Computing; R Foundation for Statistical Computing: Vienna, Austria, 2019.

67. Shemer, A.V.; Azmitia, E.C.; Whitaker-Azmitia, P.M. Dose-related effects of prenatal 5-methoxytryptamine (5-MT) on development of serotonin terminal density and behavior. Brain Res. Dev. Brain Res. 1991, 59, 59-63. [CrossRef]

68. Whitaker-Azmitia, P.M.; Azmitia, E.C. Autoregulation of fetal serotonergic neuronal development: Role of high affinity serotonin receptors. Neurosci. Lett. 1986, 67, 307-312.

69. Martin, M.M.; Liu, Y.; Wang, Z. Developmental exposure to a serotonin agonist produces subsequent behavioral and neurochemical changes in the adult male prairie vole. Physiol. Behav. 2012, 105, 529-535.

70. Kahne, D.; Tudorica, A.; Borella, A.; Shapiro, L.; Johnstone, F.; Huang, W.; Whitaker-Azmitia, P.M. Behavioral and magnetic resonance spectroscopic studies in the rat hyperserotonemic model of autism. Physiol. Behav. 2002, 75, 403-410.

71. McNamara, I.M.; Borella, A.W.; Bialowas, L.A.; Whitaker-Azmitia, P.M. Further studies in the developmental hyperserotonemia model (DHS) of autism: Social, behavioral and peptide changes. Brain Res. 2008, 1189, $203-214$.

72. Carlsson, M.L. Hypothesis: Is infantile autism a hypoglutamatergic disorder? Relevance of glutamate serotonin interactions for pharmacotherapy. J. Neural Transm. 1998, 105, 525-535.

73. Sceniak, M.P.; Fedder, K.N.; Wang, Q.; Droubi, S.; Babcock, K.; Patwardhan, S.; Wright-Zornes, J.; Pham, L.; Sabo, S.L. An autism-associated mutation in GluN2B prevents NMDA receptor trafficking and interferes with dendrite growth. J. Cell Sci. 2019, 132, jcs232892. [PubMed]

74. Liu, S.; Zhou, L.; Yuan, H.; Vieira, M.; Sanz-Clemente, A.; Badger, J.D.; Lu, W.; Traynelis, S.F.; Roche, K.W. A rare variant identified within the GluN2B C-terminus in a patient with autism affects NMDA receptor surface expression and spine density. J. Neurosci. 2017, 37, 4093-4102. [PubMed]

75. Yuen, E.Y.; Jiang, Q.; Chen, P.; Gu, Z.; Feng, J.; Yan, Z. Serotonin 5-HT1A receptors regulate NMDA receptor channels through a microtubule-dependent mechanism. J. Neurosci. 2005, 25, 5488-5501. [PubMed]

76. Field, T.; Diego, M.; Hernandez-Reif, M.; Figueiredo, B.; Deeds, O.; Ascencio, A.; Schanberg, S.; Kuhn, C. Prenatal dopamine and neonatal behavior and biochemistry. Infant Behav. Dev. 2008, 31, 590-593. [PubMed]

77. McCarthy, D.; Lueras, P.; Bhide, P.G. Elevated dopamine levels during gestation produce region-specific decreases in neurogenesis and subtle deficits in neuronal numbers. Brain Res. 2007, 1182, 11-25.

78. Money, K.M.; Stanwood, G.D. Developmental origins of brain disorders: Roles for dopamine. Front. Cell. Neurosci. 2013, 7, 260. [CrossRef] [PubMed] 
79. Laplante, F.; Nakagawasai, O.; Srivastava, L.K.; Quirion, R. Alterations in behavioral responses to a cholinergic agonist in post-pubertal rats with neonatal ventral hippocampal lesions: Relationship to changes in muscarinic receptor levels. Neuropsychopharmacol 2005, 30, 1076-1087. [CrossRef] [PubMed]

80. Freedman, R.; Ross, R.G. Prenatal choline and the development of schizophrenia. Shanghai Arch. Psychiatry 2015, 27, 90-102. [PubMed]

81. Yang, S.N.; Yang, J.-M.; Wu, J.-N.; Kao, Y.-H.; Hsieh, W.-Y.; Chao, C.C.; Tao, P.-L. Prenatal exposure to morphine alters kinetic properties of NMDA receptor-mediated synaptic currents in the hippocampus of rat offspring. Hippocampus 2000, 10, 654-662. [CrossRef]

(C) 2020 by the authors. Licensee MDPI, Basel, Switzerland. This article is an open access article distributed under the terms and conditions of the Creative Commons Attribution (CC BY) license (http://creativecommons.org/licenses/by/4.0/). 